\title{
sciendo
}

\section{THE CONCEPTS OF INLAND PASSENGER TRANSPORT IN THE ODER RIVER BASIN}

DOI 10.2478/ntpe-2018-0043

\author{
Assoc. prof. Magdalena Kaup \\ West Pomeranian University \\ of Technology Szczecin, Poland \\ dr inż. Dorota Kozowicka \\ Maritime University of Szczecin, Poland
}

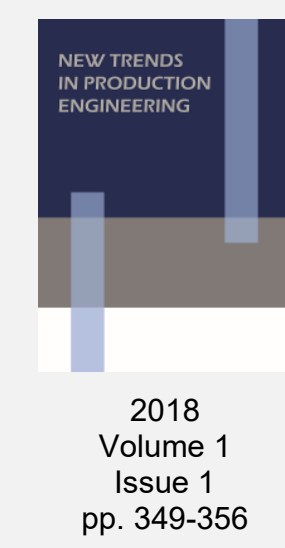

\begin{abstract}
This article presents the concepts of inland passenger transport: tourist and cruise in the basin of the Oder river. The first part describes the operating and technical parameters of the Oder and the present trends and directions in the development of inland waterway passenger services. Another part of the article contains an analysis of the results of the surveys carried out among respondents living in agglomerations lying on the Oder River. These studies have enabled the creation of two passenger transport concepts that enhance the competitiveness and attractiveness of inland waterway transport with respect to other modes of transport.
\end{abstract}

Keywords: inland shipping, passenger ship, transport, inland waterways

\section{INTRODUCTION}

Inland waterway transport makes it increasingly used in selected countries and regions for passenger transport. Both Western and Eastern European countries are characterized by good waterway parameters and only fragmentarily have parameters of classes I-III, meaning regional importance. In these countries there are many channels and channels of rivers. Inland ports and harbors are effectively adapted to the current needs of socio-economic development, and also become centers for logistics centers.

Poland also has an extensive network of navigable waterways, because of insufficient harboring, only in part is operated by inland waterways. Due to the inadequacies of inadequate depths of waterways, an increasing number of inland ports are not involved in the transport of cargo, and there is also a decline in the number of active ports (Grzelakowski, 2015). Ports are being developed in some ports for passenger handling infrastructure, which increases the flexibility of the transport sector. However, inland navigation still has a small share in the structure of transport and tourism.

Most of the river transport are carried out on the Oder River, which has enormous development potential, but at present moment its shipping capacity is very limited due to weak technical and operational parameters as well as numerous local restrictions. Current river transport represents a small share (below $0.1 \%$ ), and all inland waterway development programs have been relatively slow, as exemplified by the "Odra Program 2006". Opportunity for Oder waterway may be the development and implementation of concepts enabling the realization of passenger transport at current parameters. As shown in the publication (Galor, 2017) "an important element in sea-river shipping which is showing an increasing trend is that of passenger shipping (cruisers)."

The aim of the article is to present the concept of passenger transport for the Odra river based on the results of a survey conducted among the inhabitants of the four cities lying on the Oder River. Based on the results of the research two conceptions have been created. One of them includes waterways of Poland and Germany. It was proposed to travel on them. The second concept provides travel and communication between Szczecin and Kamień Pomorski. The route will run along the West Pomeranian Sailing Route. 


\section{TECHNICAL AND OPERATIONAL PARAMETERS OF ODER RIVER}

Oder is a river with great transport potential because it is located in three countries, namely the Czech Republic, Poland and Germany and its parameters such as the length and area of the river basin qualify it as one of the major rivers of Europe. In Poland, it flows through five voivodships (Silesian, Opole Voivodeship, Lower Silesian, Lubusz Voivodeship and West Pomeranian), linking the agglomerations: Szczecin, Wroclaw and Upper Silesian. In addition, it is a river connected to the waterways of Western Europe. Through the Oder-Spree and OderHawel channels it links the Berlin agglomerations with various areas of Poland. On the Oder, Polish ship owners make about $70 \%$ of the total national and international transport services each year. But it is still a river of regional importance. Due to the longitudinal depression of the river, the upper, middle and lower Odra are separated. The upper section of the river - from the source to Koźle - is $202 \mathrm{~km}$ long. It is a freely flowing Oder river with the nature of a mountain river and a length of about $54 \mathrm{~km}$, as well as a sewer section, where the fall is much smaller and amounts to about $0.33 \%$. The Upper Oder Canal is part of the Gliwice Canal, which has a length of $41.2 \mathrm{~km}$ and extends the Odra waterway towards Upper Silesia. The central part of the Oder runs from Koźle to Warta estuary, has slopes from 0.28 to $0.19 \%$, has a length of $522 \mathrm{~km}$. The lower part of the Oder River flows from the Warta estuary to the Szczecin Lagoon, characterized by falls from 0,05 to 0,001 (The Ecofysiographic Study for the Lower Silesian Voivodship, 2015). Table 1 shows the local shipping difficulties occurring on the Odra River, divided into sections in the upper, middle and lower part of the river.

In addition, the biggest obstacles to navigation within Szczecin water area are two railway bridges and one road bridge, which restrict access to the sea port of Szczecin and consequently to other ports of the Oder estuary.

Table 1.

Local obstacles to navigation on selected sections of the Oder

\begin{tabular}{|c|c|c|}
\hline No. & Part of the Oder River & Obstacles to navigation \\
\hline 1. & The upper section of the river & $\begin{array}{l}\text { - very curly, } \\
\text { - there are } 43 \text { arcs with radii smaller than } 600 \mathrm{~m} \text {, }\end{array}$ \\
\hline 2. & Gliwice Canal & - there is a bridge with a vertical clearance of $4.12 \mathrm{~m}$, \\
\hline 3. & $\begin{array}{l}\text { The central part- the river } \\
\text { channeled }\end{array}$ & $\begin{array}{l}\text { - lowering the water level, } \\
\text { - there are } 33 \text { arcs with radii smaller than } 600 \mathrm{~m} \text {, } \\
\text { - there are } 5 \text { bridges with a vertical clearance below } 4 \mathrm{~m} \text {, } \\
\text { - there are } 10 \text { bridges with a horizontal clearance of } 9,6 \mathrm{~m} \text {, }\end{array}$ \\
\hline 4. & $\begin{array}{l}\text { The central part- freely flowing } \\
\text { Oder river from Brzeg Dolny } \\
\text { to Nysa Łużycka estuary }\end{array}$ & $\begin{array}{l}\text { - there are } 43 \text { arcs with radii smaller than } 600 \mathrm{~m} \text {, } \\
\text { - there are } 5 \text { bridges with a vertical clearance below } 4 \mathrm{~m} \text {, and } 1 \\
\text { with vertical clearance of } 3,28 \mathrm{~m}\end{array}$ \\
\hline 5. & $\begin{array}{l}\text { The central part- freely flowing } \\
\text { Oder river from Nysa Łużycka } \\
\text { estuary to Warta estuary }\end{array}$ & $\begin{array}{l}\text { - there are the areas of shallow water, } \\
\text { - there are } 4 \text { arcs with radii smaller than } 600 \mathrm{~m}, \\
\text { - there is a bridge with a vertical clearance of } 3,67 \mathrm{~m} \text {, }\end{array}$ \\
\hline 6. & $\begin{array}{l}\text { The lower part - freely flowing } \\
\text { Oder river from the Warta } \\
\text { estuary to Szczecin }\end{array}$ & $\begin{array}{l}\text { - there are } 3 \text { arcs with radii smaller than } 650 \mathrm{~m} \text {, } \\
\text { - variability of the river current with many areas of shallow water, } \\
\text { - there is the backwater from the sea. }\end{array}$ \\
\hline
\end{tabular}
Source: own elaboration based on (Woś, 2005)

At present, on the border and the lower part of the Oder can move ships whose dimensions cannot exceed the following values: length $L=82 \mathrm{~m}$ (156 $\mathrm{m}$ for pushed convoy), width $B=11.45$ $\mathrm{m}$. List of main standards and parameters of Oder waterway is shown in Table 2.

The existing operational parameters and local obstacles on the Oder cause that the inland waterway transport is currently being carried out on the upper sewer section and the lower part of the Oder River. In addition, it is difficult to navigate in daytime only, due to the lack of 24-hour navigation markings (excluding the selected river sections). Hydro meteorological conditions are sometimes not conducive to regular shipping, both freight and passenger (Kozerska, 2016), (Łozowicka \& Kaup, 2016). 
Table 2.

List of main standards and parameters of Oder waterway

\begin{tabular}{|c|c|c|c|c|c|c|}
\hline \multirow[t]{2}{*}{ Name of the river section } & \multirow{2}{*}{$\begin{array}{c}\text { Lenght } \\
\text { of the river } \\
\text { section [km] }\end{array}$} & \multicolumn{3}{|c|}{$\begin{array}{l}\text { Ships dimensions } \\
{[\mathrm{m}]}\end{array}$} & \multirow[t]{2}{*}{$\begin{array}{l}\text { Height under } \\
\text { the bridges [m] }\end{array}$} & \multirow[t]{2}{*}{$\begin{array}{l}\text { Waterway } \\
\text { class }\end{array}$} \\
\hline & & $\mathbf{L}$ & B & $T$ & & \\
\hline $\begin{array}{l}\text { Szczecin-Widuchowa } \\
\text { (The lower part of the Oder) }\end{array}$ & 37.50 & 82.00 & 11.45 & 2.50 & 5.17 & IV \\
\hline $\begin{array}{l}\text { Widuchowa-Warta estuary } \\
\text { (The lower part of the Oder) }\end{array}$ & 86.50 & 82.00 & 11.45 & 1.80 & 4.54 & IV \\
\hline $\begin{array}{l}\text { Warta estuary-Nysa Łużycka estuary } \\
\text { (The central part of the Oder) }\end{array}$ & 75.20 & 82.00 & 11.45 & 1.40 & 4.47 & III \\
\hline $\begin{array}{l}\text { Nysa Łużycka estuary-Brzeg Dolny } \\
\text { (The central part of the Oder) }\end{array}$ & 259.80 & 70.00 & 9.00 & 1.20 & 3.72 & II \\
\hline $\begin{array}{l}\text { Brzeg Dolny-Koźle (The upper section } \\
\text { of the river) }\end{array}$ & 187.00 & 70.00 & 9.00 & 1.60 & 3.72 & III \\
\hline Gliwice Canal & 41.20 & 70.00 & 11.40 & 1.70 & 4.04 & III \\
\hline
\end{tabular}

Source: Inventory of main standards and parameters of the E waterway Network, 2012

The Oder River Region has great potential both for economic and tourist purposes, but Poland is a country where inland waterways are not fully utilized for tourist purposes. There are regions where seasonal tourism, tourist and sightseeing tours, or cruises, usually from May to the end of September, are performed. The main centers are located on the canals and lakes of the Ostróda-lława Lake District, the Augustow Channel, the Great Masurian Lakes, as well as in selected coastal towns along the Odra River, the Vistula River, the Warta River and others. These services are handled by shipping companies (eg. Polsteam Żegluga Szczecińska) or by private carriers, which usually have fewer vessels. Inland transport is handled by shipping companies (eg. Polsteam Żegluga Szczecińska) or by private carriers, which usually have fewer barges.

On Oder, transport is carried out most in Wroclaw and in Szczecin and Świnoujście. Statistical data show that in Poland in the 1980s, more than 9 million passengers were transported, in the 90 s it was only less than 4 million, and there was a further decline in transport. After 2000 (1.2 million passengers were transported), a small increase in the number of passengers was noted. At present, over 1.5 million passengers are transported. Most of the services carried out are day trips, with an average distance of 12 kilometers (Inland waterway transport in Poland in 2014, Inland waterway transport in Poland in the years 2010-2013). Table 3 shows the volume of passenger traffic for 2010-2014.

Table 3.

Inland waterway transport along with offshore navigation in Poland in 2010-2014

\begin{tabular}{|l|c|c|c|c|c|}
\hline Specification & $\mathbf{2 0 1 0}$ & $\mathbf{2 0 1 1}$ & $\mathbf{2 0 1 2}$ & $\mathbf{2 0 1 3}$ & $\mathbf{2 0 1 4}$ \\
\hline Number of passengers [thousands of passengers] & 1396 & 1519 & 1515 & 1540 & 1579 \\
\hline Transportation work [Million pkm] & 23.3 & 24.3 & 23.8 & 20 & 19 \\
\hline Average distance traveled by one passenger [km] & 17 & 16 & 16 & 12 & 12 \\
\hline
\end{tabular}

Source: own elaboration based on (Inland waterway transport in Poland in 2014, Inland waterway transport in Poland in the years 2010-2013)

Because of the diverse hydro technical development and the different technical parameters along the entire length of the waterways, tourism and leisure activities are increasingly popular on inland waterways, which do not meet the requirements of international shipping and even for regional shipping.

In 2004, a European classification of recreational waterways was introduced to facilitate the development of water tourism. Table 4 shows the classification of recreational waterways.

At present, in order to increase the volume of passenger transport and their attractiveness, innovation and appropriate standards should be ensured:

1. in the area of port facilities and passenger docks;

2. in the area of passenger service;

3. on currently operated inland tourist and transport vessels. 
Table 4.

Classification of waterways of recreational importance

\begin{tabular}{|l|l|c|c|c|c|}
\hline \multirow{2}{*}{ Waterway class } & \multicolumn{2}{|c|}{ Ship type } & \multicolumn{2}{c|}{$\begin{array}{c}\text { The dimensions of the ship } \\
\text { (length, breadth, draft) }\end{array}$} & $\begin{array}{c}\text { Minimum height } \\
\text { under the bridges }\end{array}$ \\
\cline { 3 - 6 } & & $\mathbf{L}[\mathbf{m}]$ & $\mathbf{B}[\mathbf{m}]$ & $\mathbf{T}[\mathbf{m}]$ & $\mathbf{H}$ [m] \\
\hline RA & Open boat & 5.50 & 2.00 & 0.50 & 2.00 \\
\hline RB & Cabin yacht & 9.50 & 3.00 & 1.00 & 3.25 \\
\hline RC & Motor yacht & 15.00 & 4.00 & 1.50 & 4.00 \\
\hline RD & Sailboat & 15.00 & 4.00 & 2.10 & 30.00 \\
\hline
\end{tabular}

Source: (European Recreational Inland Navigation Network, 2014)

The current trends in inland passenger transport include the use of innovative ships, including solar electric vehicles, as well as low-draft vessels, so that they can reach previously inaccessible places (Litwin et al, 2017), (Abramowicz-Gerigk et al, 2017), (Gao et al, 2017). Another way to develop passenger services can be cruising on routes with interesting infrastructure (eg. the Niderfinow lift shown in Figure 1) or near interesting places of historical interest or landscape values.

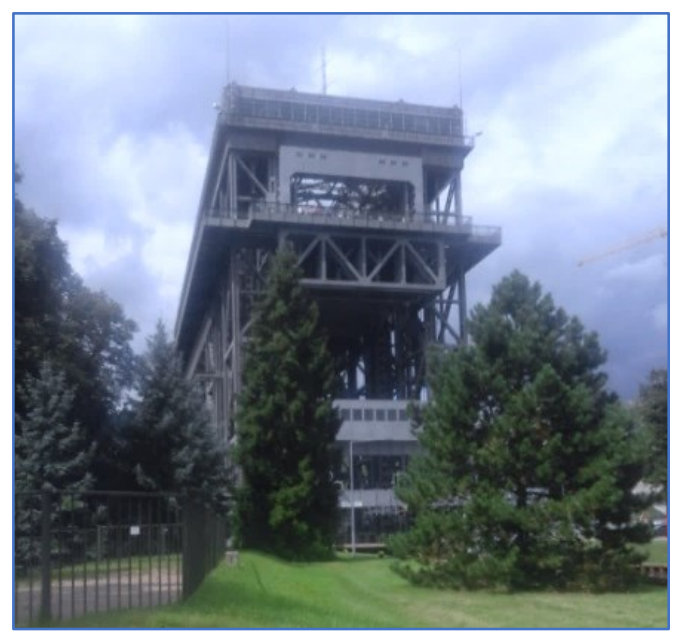

Source: own.

Fig. 1. Ship lift in Niderfinow.

An interesting concept of using inland waterways as an alternative to urban transport is presented in the publication (Jastrzębski et al, 2005). Another idea might be to use inland waterways to locate residential barges (Łozowicka et al., 2016), (Kaup et al., 2016).

\section{ANALYSIS OF THE SURVEY REGARDING THE ASSESSMENT OF THE FUNCTIONING OF PASSENGER INLAND TRANSPORT}

Survey studies were used to assess the attractiveness and the extent of the use of inland passenger transport in Poland.

The research was carried out in selected cities of the Oder, i.e. Szczecin, Wroclaw, Krosno Odrzańskie, Cigacice and Nowa Sól. The survey was conducted in June, July and August 2016, with 344 respondents. Table 5 shows the results of the surveys.

The conducted surveys have shown that:

- People are not fully informed about current passenger services offered by shipping companies in the region.

- People are very positive about the different forms of passenger shipping and believe that they should be developed.

- Travel and excursion would enjoy much more popularity and interest, even several times per season, provided they were properly promoted and advertised.

- More than half of respondents do not have full information on inland passenger transport.

- Among passenger services, the tourist, communication and excursion services are most popular. 
Table 5.

Table with survey results

\begin{tabular}{|c|c|c|c|c|c|}
\hline \multirow{2}{*}{ No. } & \multirow{2}{*}{ Questionnaire question } & \multicolumn{4}{|c|}{ Respondents' answers } \\
\hline & & Yes & No & \multicolumn{2}{|c|}{ I have no opinion } \\
\hline 1. & $\begin{array}{l}\text { Are there inland passenger transport } \\
\text { near your place of residence? }\end{array}$ & 134 & 78 & \multicolumn{2}{|r|}{132} \\
\hline 2. & $\begin{array}{l}\text { Do you think that passenger transport by } \\
\text { inland waterway is attractive? }\end{array}$ & 248 & 40 & \multicolumn{2}{|r|}{56} \\
\hline 3. & $\begin{array}{l}\text { Do you know the current offer of inland } \\
\text { passenger transport in the region? }\end{array}$ & 12 & 218 & \multicolumn{2}{|r|}{114} \\
\hline 4. & $\begin{array}{l}\text { Is passenger transport sufficiently } \\
\text { promoted / advertised in your region? }\end{array}$ & 40 & 270 & \multicolumn{2}{|r|}{34} \\
\hline 5. & $\begin{array}{l}\text { Would you use inland transport if it } \\
\text { would be implemented in the region? }\end{array}$ & 298 & 12 & \multicolumn{2}{|r|}{34} \\
\hline 6. & $\begin{array}{l}\text { Would you use inland transport and } \\
\text { cruise if you would be in the region? }\end{array}$ & 322 & 8 & \multicolumn{2}{|r|}{14} \\
\hline & & $\mathbf{T U}^{*}$ & $\mathrm{CM}^{* *}$ & $E X^{* * *}$ & $A^{* * * *}$ \\
\hline 7. & $\begin{array}{l}\text { What type of passenger transport } \\
\text { is carried out in your region? }\end{array}$ & 128 & 24 & 120 & 168 \\
\hline \multirow[t]{2}{*}{8.} & $\begin{array}{l}\text { What kind of passenger transport should } \\
\text { be carried out in your area? }\end{array}$ & 134 & 48 & 116 & 176 \\
\hline & & $\begin{array}{l}\text { Once } \\
\text { a season }\end{array}$ & $\begin{array}{c}\text { Several } \\
\text { times } \\
\text { a season }\end{array}$ & \multicolumn{2}{|r|}{ At all } \\
\hline \multirow[t]{2}{*}{9.} & $\begin{array}{l}\text { How often would you use tourist, } \\
\text { communication and excursion transport } \\
\text { if it would be available in the region? }\end{array}$ & 128 & 206 & & 10 \\
\hline & & $\begin{array}{l}\text { Up to } 26 \\
\text { years old }\end{array}$ & $\begin{array}{l}\text { 26-50 years } \\
\text { old }\end{array}$ & \multicolumn{2}{|c|}{ Over 50 years old } \\
\hline 10 & How old are you? & 190 & 102 & & 52 \\
\hline
\end{tabular}

Source: own elaboration

\section{ANALYSIS OF VARIABLES OF PASSENGER TRANSPORT IN ODER RIVER BASIN}

Taking into account the survey results and the conditions in the Oder river basin, the following variants of inland passenger transport may be proposed:

- Excursions, which are characterized by multi-day cruises along the interesting areas with accommodation places designated in individual ports or with the possibility of overnight accommodation on the ship. Ships should provide high standard and comfort of travel.

- Tourist-communication services characterized by several-hour-day cruises. They can complement existing communication in the area (eg. in the form of water trams). Ships sail in accordance with pre-determined cruise schedules and return to the starting point on the same day.

In the Oder river basin it is possible to carry out both modes of transport, which may vary, but due to the very varied parameters of the waterway, their range of operation is limited. The most likely for rapid implementation are two concepts:

- Variant 1 - tourist-communication services on the Szczecin-Kamień Pomorski route.

- Variant 2 - international excursions on Polish and German waterways.

The route for Variant 1 is shown in Figure 2. The route is planned along the West Pomeranian Sailing Route, which includes the Danube, the Grodzki Canal, the Western Oder River, the Szczecin Lagoon, the Stepnica Bay, the Deep Stream, the Dziwna River, the Gulf of Silence and the Lagoon of Kamień Pomorski. The planned route Szczecin-Kamien Pomorski is approximately $91 \mathrm{~km}$. In Szczecin, a marina located on the Grodzka Island is planned as the starting point. There are 3 stops on the designated route where passengers will be able to live the ship. It was assumed that each time the ship stops, it will be 20 minutes. These points are located in Stepnica, Trzebież and Wolin. Short characteristics of the start, destination and intermediate points are shown in Table 6. 


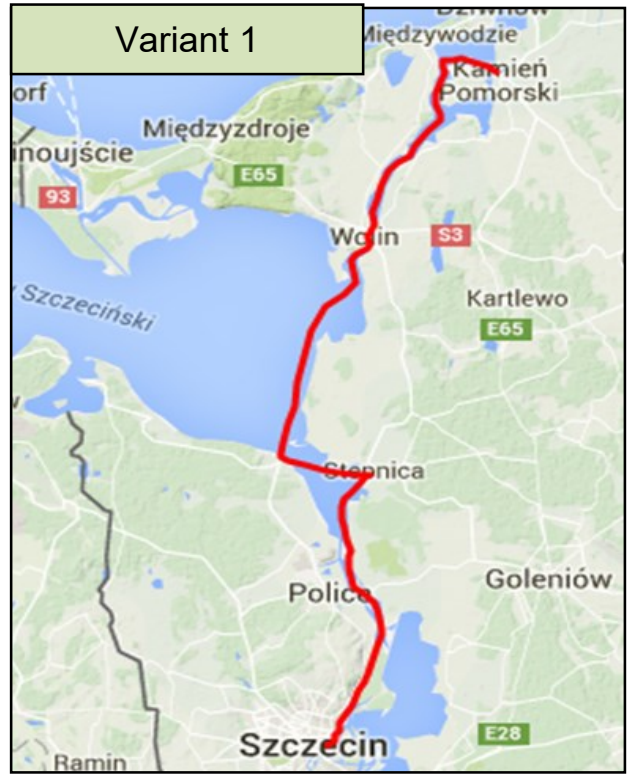

Fig. 2. Route of tourist-communication transport.

Source: own elaboration based on (Sailing Europe Interactive Route Planner)

Table 6.

Characteristics of marinas along the tourist-communication route

\begin{tabular}{|c|c|c|}
\hline No. & $\begin{array}{l}\text { Location of the } \\
\text { marina }\end{array}$ & Comment \\
\hline 1. & $\begin{array}{l}\text { Grodzka Island- } \\
\text { Szczecin }\end{array}$ & $\begin{array}{l}\text { - it has } 70 \text { mooring locations and is expected to be } 150 \text { places in the future } \\
\text { - equipped with installations for operating vessels, } \\
\text { - provides access to electricity, drinking water, toilets and showers, } \\
\text { - is adapted to the movement and sailing of invalids }\end{array}$ \\
\hline 2. & Stepnica & $\begin{array}{l}\text { - it has } 250-300 \text { mooring locations, } \\
\text { - depth of the aquifer is } 2.50 \mathrm{~m} \text {, } \\
\text { - it is equipped with necessary media and service points ie shops, bars, } \\
\text { banks, etc. }\end{array}$ \\
\hline 3. & Trzebież & $\begin{array}{l}\text { - it has } 120 \text { mooring locations, } \\
\text { - depth of the aquifer is about } 4 \mathrm{~m} \text {, } \\
\text { - it has access to all media and service points, } \\
\text { - in the port area there are border and customs clearance, } \\
\text { - near the marina there is a public transport stop, }\end{array}$ \\
\hline 4. & Wolin & $\begin{array}{l}\text { - it is possible to approach the marina from both sides: from the south to the } \\
\text { Lagoon and from the } \\
\text { north to the Baltic, with the approach from the Lagoon being shorter and } \\
\text { easier, } \\
\text { - on the southern approach the depth reaches } 2.5 \mathrm{~m} \text {, and at the north } 2 \mathrm{~m} \text {, } \\
\text { - the number of mooring locations depends on the size of the ship, whereby } \\
\text { available is } 180 \mathrm{~m} \text { quay, }\end{array}$ \\
\hline 5. & Kamień Pomorski & $\begin{array}{l}\text { - it is located near the old town, } \\
\text { - it has } 240 \text { mooring locations, } \\
\text { - depth of the aquifer is } 2.50 \mathrm{~m}, \\
\text { - it has a sports equipment rental and additional services, } \\
\text {-it has accommodation, social facilities (toilets, showers, laundry with drying } \\
\text { room, kitchen, sailing shop, cafes) and technical (pedestals with water and } \\
\text { electricity,, reception, internet). } \\
\text { - near the marina there is a bus stop and a railway station, }\end{array}$ \\
\hline
\end{tabular}

Source: own elaboration based on (The Ecofysiographic Study for the Lower Silesian Voivodship, 2005)

There are good technical and navigational conditions on the route. The clearances under the bridges and the depths of the entire route allow for safe tourist and communication sailing. The impact on the depth of the waterway includes inter alia the proximity to the Baltic Sea, the implementation of selected investments within the project "West Pomeranian Sailing Route" and the international route "E30".

The route for Variant 2 is shown in Figure 3. 


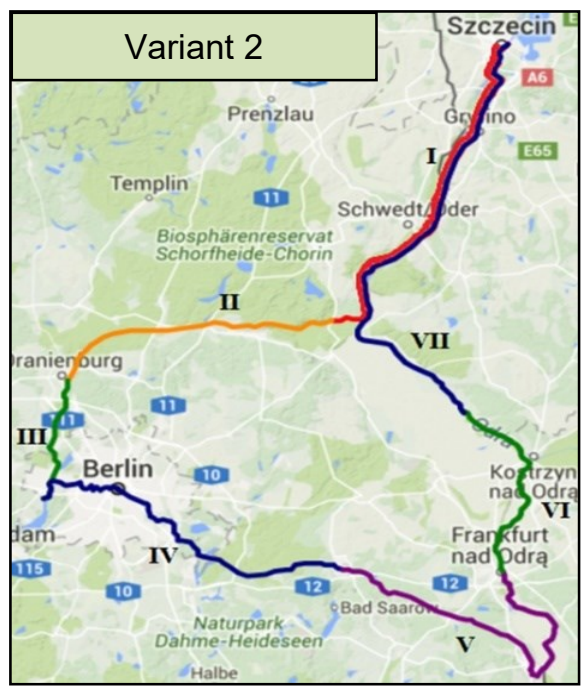

Fig. 3. Route of excursion with the division into sections.

Source: own elaboration based on (Sailing Europe Interactive Route Planner)

The route was planned along the following locations: Szczecin, Gryfino, Cedynia, Eberswalde, Oranienburg, Berlin, Fürstenwalde, Eisenhüttenstadt, Frankfurt/Oder and Kostrzyn upon Oder. The designated route is about $568 \mathrm{~km}$ long.

The planned route runs along the Oder River, then the Oder-Havel Canal, the Havel River, the Spree River, the Dahme River, the Oder-Spree Canal and the Oder River again to Szczecin.

Table 7.

Characteristic of the excursion sections

\begin{tabular}{|c|c|c|}
\hline No. & Section of the route & Comment \\
\hline 1. & Szczecin-Oderberg & $\begin{array}{l}\text { - the length of the route is about } 94 \mathrm{~km} \\
\text {-there is the Hohensaaten water lock - lifting } 1.9 \mathrm{~m} \\
\text { - it is part of the Oder waterway and Oder - Hawel waterway }\end{array}$ \\
\hline 2. & Oderberg-Oranienburg & $\begin{array}{l}\text { - the length of the route is about } 69 \mathrm{~km} \\
\text { - there are two water locks: Niederfinów - lifting } 36 \mathrm{~m} \text { and } \\
\text { Lechnitz - lifting } 6 \mathrm{~m} \\
\text { - it is part of the Oder - Hawel waterway }\end{array}$ \\
\hline 3. & Oranienburg-Berlin & $\begin{array}{l}\text { - the length of the route is about } 35 \mathrm{~km} \text {, } \\
\text { - there is the Spandau water lock - lifting } 2.8 \mathrm{~m} \\
\text { - it is part of the Oder - Hawel waterway }\end{array}$ \\
\hline 4. & Berlin-Furstenwalde & $\begin{array}{l}\text { - the length of the route is about } 91 \mathrm{~km} \text {, } \\
\text { - there are four water locks: Charlottenburg lifting } 1.2 \mathrm{~m} \text {, } \\
\text { Mühlendamn - lifting } 1.5 \mathrm{~m} \text {, Wernsdorf lifting }-4.5 \mathrm{~m} \text {, } \\
\text { Furstenwalde- lifting } 0.9 \mathrm{~m} \text {, } \\
\text { - it is part of the Oder - Spree waterway, }\end{array}$ \\
\hline 5. & Furstenwalde-Słubice & $\begin{array}{l}\text { - the length of the route is about } 97 \mathrm{~km} \text {, } \\
\text { - there are two water locks: Kersdorf - lifting } 2.3 \mathrm{~m} \text {, } \\
\text { Eisenhüttenstadt - lifting - } 14 \mathrm{~m} \text {, } \\
\text { - it is part of the Oder waterway and Oder- Spree waterway }\end{array}$ \\
\hline 6. & Słubice-Kienitz & $\begin{array}{l}\text { - the length of the route is about } 57 \mathrm{~km} \text {, } \\
\text { - it is part of the Oder waterway }\end{array}$ \\
\hline 7. & Kienitz-Szczecin & $\begin{array}{l}\text { - the length of the route is about } 125 \mathrm{~km} \text {, } \\
\text { - it is part of the Oder waterway }\end{array}$ \\
\hline
\end{tabular}

Source: own elaboration based on (Blue Book Database)

The designated route coincides with the international waterways "E30", "E70", "E71" and "E7010". It was divided into 7 sections. Each section is scheduled for a single day of travel, ending at the location of the selected marina, where it is planned to stay with accommodation. The short description of the individual sections of the route is presented in Table 7.

There are 10 water locks on the whole planned route, each one is free. The length and speed of the cruise of each section depend mainly on the attractiveness of the regions in which they are located. The Niderfinow and Eisenhüttenstadt can be an interesting tourist attraction. 


\section{CONCLUSION}

Poland has an extensive network of inland navigable waterways, where the Oder river has the greatest natural potential for the development of inland waterway passenger transport. Utilizing this potential can create conditions for the development of trade and tourism of the Oder region. The questionnaire survey was used in the article to assess the attractiveness and the current use of inland waterway passenger transport. The results of the study have shown public expectations of inland waterway transport in the area of passenger service. On the basis of them, two concepts of transport: tourist- communication and excursion, starting at the marina in Szczecin were proposed. Similar concepts could also be implemented in other cities of the Oder, but for other transport units due to the lower parameters of inland waterways.

\section{REFERENCES}

Grzelakowski, A. S.(2015). Inland Water Transport and its Impact on Seaports and Seaport Cities Development. Information, communication and environment: Marine navigation and safety of sea transportation. Edited by: Weintrit, A; Neumann, T.

Galor, W. (2017). Sea-river shipping in Polish inland waters. Scientific Journals of the Maritime University of Szczecin, no. 50

Kozerska, M. (2016). Inland waterway transport in Poland - the current state and prospects for development Scientific Journals of the Maritime University of Szczecin, no. 47

Łozowicka, D., Kaup, M. (2016). Aspekty bezpieczeństwa transportu wodnego śródlądowego w Polsce. Technika Transportu Szynowego 12/2015

The Ecofysiographic Study for the Lower Silesian Voivodship (2005) Wroclaw Voivodship Urban Office. Wrocław. Available at: http://marinas.pl/ [Accessed 12 Apr. 2017].

Woś, K. (2005). Kierunki aktywizacji działalności żeglugi śródlądowej w rejonie ujścia Odry w warunkach integracji Polski z Unią Europejską, Warsaw: Indruk.

Inventory of main standards and parameters of the E waterway Network, "Blue Book". (2012). Economic commission for Europe. United Nations, New York and Geneva, ECE/TRANS/SC.3/144/Rev.2

Inland waterway transport in Poland in 2014. (2015) Central Statistical Office, Signal Processing, Warsaw.

Inland waterway transport in Poland in the years 2010-2013. (2014), Central Statistical Office, Warsaw.

European Recreational Inland Navigation Network. (2014). Resolution no. 52, United Nations, New York and Geneva.

Litwin, W., Leśniewski, W., Kowalski, J. (2017). Energy Efficient and Environmentally Friendly Hybrid Conversion of Inland Passenger Vessel. Polish Maritime Research Volume 24, Issue 4.

Abramowicz-Gerigk, T., Burciu, Z., Jachowski, J. (2017). An Innovative Steering System for a River Push Barge Operated in Environmentally Sensitive Areas. Polish Maritime Research Volume 24, Issue 4.

Gao, D., Zhang, W., Shen, A. (2017). Parameter Design and Energy Control of the Power Train in a Hybrid Electric Boat. Energies. Volume 10, Issue 7.

Jastrzębski T., Sułek J., Tołkacz L., Żurawski T. (2005). River Tramway - an Alternative Solution for Sustainable Passenger Urban Transport System. Scientific Journals of the Maritime University of Szczecin, no. 9

Łozowicka D., Kaup M., Machowski Z. (2016). Legal aspects of using inland surface waters to satisfy residential needs in Poland. Scientific Journals of the Maritime University of Szczecin, no. 48

Kaup M., Łozowicka D., Machowski Z. (2016). The concept of multipurpose inland residential platforms used on European waterways. Scientific Journals of the Maritime University of Szczecin, no. 47

Sailing Europe Interactive Route Planner, Available at: http://www.sailingeurope.com/pl/trasy-iflotylle/planer-trasy [Accessed 12 Apr. 2017].

Blue Book Database. Economic commission for Europe, Available at: http://apps.unece.org/AGN/ [Accessed 12 Apr. 2017]. 